\title{
Impact of the Flipped Classroom on Students' Learning Performance via Meta-Analysis
}

\author{
Mingming Shao, Xiaohong Liu* \\ School of Education Science, Nanjing Normal University, Nanjing, China \\ Email: ^200602126@njnu.edu.cn
}

How to cite this paper: Shao, M. M., \& Liu, X. H. (2021). Impact of the Flipped Classroom on Students' Learning Performance via Meta-Analysis. Open Journal of Social Sciences, 9, 82-109.

https://doi.org/10.4236/jss.2021.99007

Received: July 18, 2021

Accepted: August 30, 2021

Published: September 2, 2021

Copyright (อ 2021 by author(s) and Scientific Research Publishing Inc. This work is licensed under the Creative Commons Attribution International License (CC BY 4.0).

http://creativecommons.org/licenses/by/4.0/ (c) (i) Open Access

\begin{abstract}
The flipped classroom is a teaching strategy that reconstructs conventional teaching methods and pays attention to students' active learning. Recently, there have been many studies comparing the effects of flipped and traditional classrooms on students' learning outcomes, but which is more suitable remains an open issue. This study explored the effect of flipped classrooms on student learning performance compared to traditional classrooms via meta-analysis. Using predefined eligibility criteria to screen the literature, WoS databases were searched for the relevant articles, and 63 experimental articles were included in the meta-analysis. STATA was used to conduct the current meta-analysis. The results indicated that the flipped classroom can improve students' academic performance. The subgroup analysis showed that the heterogeneity of each subgroup was relatively large, and the sensitivity analysis found that the source of heterogeneity might be caused by the different experimental designs and the specific implementations of the flipped classrooms. The results provide a broad perspective for educators to implement flipped classrooms in the future.
\end{abstract}

\section{Keywords}

Flipped Classroom, Meta-Analysis, Learning Performance, Quasi-Experiment, Subgroup Analysis

\section{Introduction}

The flipped classroom is a hybrid approach that combines online learning with face-to-face classroom activities (Graham, Woodfield, \& Harrsison, 2013). It inverts the traditional instruction strategy. Before the class, the teacher provides videos or other resources and the students choose a suitable time and place to learn based on their personal learning rhythm; in the class, the students partici- 
pate in collaborative and interactive learning activities to make good use of the class time (Bergmann \& Sams, 2012; Fulton, 2012; Mok, 2014). With the development of digital resources, particularly the open online instructional videos created by Khan Academy and the massive open online courses (MOOC), the flipped classroom has become increasingly popular in modern education (Sun, Xie, \& Anderman, 2018). In line with this, this study aims to investigate whether flipped classrooms can promote students' learning performance in different subject areas and learning stages, and whether students' academic performance in flipped classrooms has different effects due to the different types of knowledge taught.

Flipped classrooms allow students to achieve better outcomes in the class with less brain power or cognitive input (Clark, Nguyen, \& Sweller, 2006; Jensen, Kummer, \& Godoy, 2006; Mattis \& Kristina, 2015). Zainuddin, Haruna, Li, Zhang, and Chu (2019) divided the impact of the flipped classroom implementation into learning achievement, learning motivation or learning engagement, self-efficacy and social interaction. Some experimental studies have found that students under the flipped classroom gained better learning performance (e.g., Alamri, 2019; Jdaitawi, 2019; Kazanidis, Pellas, Fotaris, \& Tsinakos, 2019; Lo, Lie, \& Hew, 2018), motivation or engagement (e.g., Chuang, Weng, \& Chen, 2018; Sergis, Sampson., \& Pelliccione, 2018), self-efficacy (e.g., Bouwmeester, de Kleijn, van den Berg, ten Cate, van Rijen, \& Westerveld, 2019; Ng, 2018), social communication (e.g., Jdaitawi, 2019; Sun et al., 2018), creativity and critical thinking (e.g., Rodriguez, Diez, Perez, Banos, \& Carrio, 2019), and learning attitude (e.g., Turra, Carrasco, Gonzalez, Sandoval, \& Yanez, 2019). On the other hand, many published articles indicate that there is no statistically significant difference in the impact of flipped classrooms on student achievement compared to traditional classrooms (e.g., Burnham \& Mascenik, 2018; Cabi, 2018; Smallhorn, 2017; Tse, Choi, \& Tang, 2017). Students accustomed to traditional instruction may find it difficult to accept the flipped classroom instruction and they may not devote much passion to self-directed learning, especially out of class (Talbert 2015). In addition, compared with regular courses, flipped courses have been found to have no positive effect on students' learning motivation (Tse et al., 2017). To sum up, it is hard to reach a consistent conclusion regarding whether the flipped classroom instructional strategy has a significant impact on students. Therefore, the present study aimed to expand the perspective of previous meta-analyses and reviews by investigating the impact of flipped classroom interventions comparing the traditional classroom with students' learning performance. Furthermore, the present study explored whether the flipped classroom's specific implementation characteristics moderate the learning outcomes.

\section{Literature Review}

\subsection{Previous Meta-Analyses on Flipped Classroom}

Existing studies have discussed the impact of implementing the flipped class- 
room on students in the medical and health profession disciplines. Chen et al. (2018) compared the efficacy of the flipped classroom with traditional lecturebased learning with 46 studies in the field of medicine, and found that the students who experienced flipped classrooms had higher learning performance than those who learned in traditional classrooms. Hew and Lo (2018) found that the flipped classroom strategy in health profession education produces a significant improvement in student learning performance compared with regular courses according to 28 eligible comparative studies. Hu et al. (2018) analyzed the effectiveness of flipped classroom teaching in nursing courses according to 11 articles, and found that it was effective in terms of improving students' scores of theoretical knowledge and skills. Xu et al. (2019) also conducted a meta-analysis to explore the effectiveness of inverted classrooms on the development of Chinese nursing students' skill competence through 22 eligible studies. The metaanalysis results of Gillette et al. (2018) reached different conclusions, as they found that there was no significant difference in the student performance of traditional and flipped classrooms by conducting a meta-analysis of five articles published in the field of pharmacy education between 2000 and 2017.

Ang, Zaid, and Harun (2015) conducted a meta-analysis on 10 articles published since 2010 related to flipped classrooms, social collaboration knowledge construction (SCKC), and information and communication technology (ICT) courses. The study of Ang et al. (2015) was concerned with the effectiveness of flipped classrooms on college students' scientific production and found that the flipped classroom model is conducive to promoting the construction of students' social collaboration knowledge and ICT skills. Martínez, Díaz, Rodríguez and García (2019) evaluated the effect of the flipped classroom teaching method on college students' learning performance through the research included in the WOS and Scopus database, and the results showed that students' learning performance was improved under the flipped classroom.

There are also studies which are not limited to certain subject areas or learning stages. Rahman, Aris, Mohamed and Zaid (2014) found that the flipped classroom instructional strategy is suitable for integrating into mathematics, science, engineering, technology and social science and other disciplines, and has a positive effect on students' test scores by 15 relevant articles published in 2009-2014. However, Cheng, Ritzhaupt and Antonenko (2019) found that the flipped course had a negative effect $(g=-0.081)$ on student outcomes under the context of engineering education. Cheng et al. (2019) analyzed the impact of flipped classrooms on students' learning outcomes by a set of moderating variables including students' learning stage, subject area, duration of study, and publication type, and found that the effect sizes were significantly moderated by subject area. Lag and Saele (2019) meta-analyzed eligible papers published after 2010 to evaluate the impact of flipped classrooms compared with traditional classrooms on learning outcomes and student satisfaction, and the results showed that flipped classrooms had little impact on learning $(g=0.35)$. Briefly, there are several meta-analyses of the effectiveness of flipped classrooms in certain disciplines or in- 
volving certain groups of students. However, they did not explore whether the types of knowledge taught in the flipped classrooms also affect students' academic performance.

\subsection{Research Questions}

Previous meta-analyses have covered a broad range of overall effects, but most studies are limited to a certain subject area (e.g., Chen et al., 2018; Gillette et al., 2018; Hew \& Lo, 2018; Hu et al., 2018), discipline (e.g., Ang et al., 2015; Martínez et al., 2019; Xu et al., 2019) or educational level (e.g., Martínez et al., 2019). There are a few articles (e.g., Cheng et al., 2019; Lag \& Saele, 2019) which have examined the potential moderating effects of flipped classrooms and explored whether specific characteristics of the implementation moderate the impact. Wasserman, Quint, Norris, and Carr (2015) found that the different proportions of conceptual knowledge and procedural knowledge in the learning content will affect the outcomes of students under the flipped instructional model. Therefore, based on previous researchers' findings, subjects and knowledge types are also included in the moderating variables in the present study to explore the differences in the learning effects of the flipped classroom from all disciplines. The current meta-analysis aims to answer the following two research questions:

RQ1: Can the flipped classroom instructional strategy effectively improve students' learning performance?

RQ2: Is the students' performance in the flipped classroom instructional strategy moderated by specific characteristics, such as RQ2-1: study design, RQ2-2: sample size, RQ2-3: learning stage, RQ2-4: subject area, RQ2-5: knowledge type, RQ26: instructor equivalence, RQ2-7: and intervention duration?

\section{Method}

\subsection{Search Strategy and Selection Criteria}

In order to ensure that the search of the literature that constitutes the study samples is rigorous, this study followed the PRISMA (Preferred Reporting Items for Systematic Reviews and Meta-analyses) statement of the eligibility criteria and quality criteria of research selection (Moher, Liberati, Tetzlaff, Altman, \& The PRISMA Group, 2009). The retrieval took place on January 1, 2019. To capture high-quality and a broader range of potential and eligible papers, we conducted the following search strings with Boolean operators to identify the relevant papers in the core collection retrieval of the WOS (Web of Science) data-

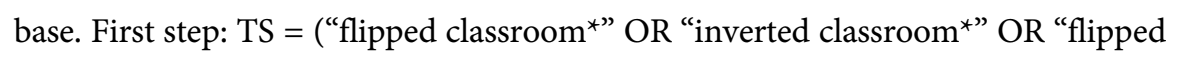
learning"); second step: TS = ("academic performance " OR "academic achievement ${ }^{\star}$ " OR "learning performance ${ }^{\star}$ ” OR effect ${ }^{\star}$ OR impact ${ }^{\star}$ OR efficacy OR performance ${ }^{\star}$ OR achievement ${ }^{\star}$ ) AND \#1, where \#1 represents the results obtained in the first retrieval step. The results returned 595 articles written in English during the time span of 2012-2018.

The following inclusion criteria were used to decide which paper could be in- 
cluded in this meta-analysis. According to the inclusion criteria, 595 papers were screened, and the flowchart is shown in Figure 1.

Inclusion Criterion 1: The papers utilized comparative studies such as quasi-experiments and randomized controlled trial.

Inclusion Criterion 2: The experimental group adopted the flipped classroom instructional strategy, while the control group adopted the conventional classroom instructional strategy.

Inclusion Criterion 3: The papers reported the learning performance of the experimental group and the control group on similar course topics using the identical assessment instruments.

Inclusion Criterion 4: The papers provided enough data to calculate effect size, such as mean and standard deviation.

\subsection{Coding of the Outcome Variables}

In the current study, 63 sample papers were coded according to the coding methods of Chen et al. (2018) and Cheng et al. (2019). In addition, we also wanted to explore the impact of knowledge type on students' learning performance in flipped classrooms. Learning content was classified according to the dimensions of knowledge structure (Krathwohl, 2002). Thus, 63 eligible papers were coded according to basic information, characteristics of the learner, content attributes of learning materials. The specific coding content is as follows: 1) The basic information includes author, publication time, sample size, type of experiment,
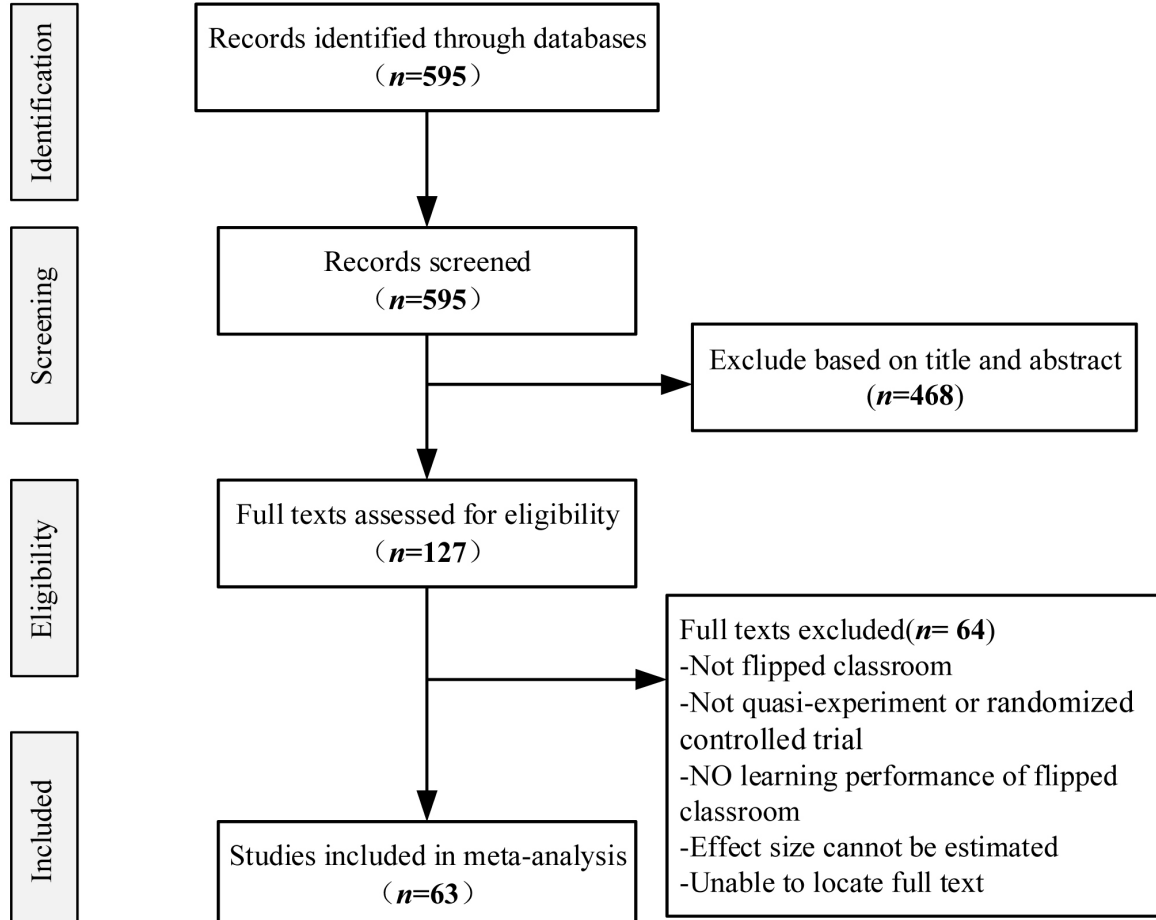

Figure 1. Flowchart of inclusion of studies. ${ }^{\star}$ Some studies included more than one learning performance. 
duration of intervention; 2) The characteristics of learners include the learning stage of the participants, such as elementary school, middle school, high school, university; and 3) The content of the study mainly analyzes the type of knowledge and the subject area.

To ensure the reliability of the coding, each of the authors coded five papers and analyzed the inconsistent codes to form a consistent understanding of the coded content. Then, each of us coded all of the sample papers separately. After coding, all the authors discussed the different opinions to form a consensus and correct the results. The coding results of the 63 papers are shown in Table A1 of the Appendix. Among them, Lo et al. (2018) conducted four comparative experiments to explore the effect of flipped classrooms on students' outcomes in secondary school. Since the four experiments were performed on four different subject areas, those four sets of data were all included in the meta-analysis. Therefore, the number of effect sizes from 63 sample papers is $66(k=66)$.

\subsection{Effect Size Extractions and Calculations}

The effect size (sometimes referred to as correlation or standardized mean difference) is the unit of currency in a meta-analysis, which quantifies the magnitude between the control group and treated group or the strength of a relationship between two variables (Borenstein, Hedges, Higgins, \& Rothstein, 2010). STATA (Version 12.0) was used to estimate the effect size between the flipped classroom and the conventional classroom from the final examination scores of the post-tests. When screening the literature, most of the articles reported the students' post-test scores, and a few also measured the students' satisfaction and motivation. Thus, this study only focuses on the students' academic achievements and puts the post-test results into the calculation to acquire the average effect size of 63 sample papers. Before performing meta-analysis, it is necessary to standardize the effect size of each article. Lo et al. (2018) provide data on four different sets of samples to obtain four effect sizes, while the other 62 papers only have one effect size.

In a meta-analysis, both Hedges' $\mathrm{g}$ and Cohen's $\mathrm{d}$ can be used to standardize the effect size. However, when the sample size is small, the calculation method of Hedges' $g$ is more accurate (Borenstein et al., 2010). Thus, Hedges' g was chosen to measure the effect size. The calculation formula of Hedges' $g$ is as follows (Borenstein et al., 2010; Cooper, Hedges, \& Valentine, 2009).

$$
\begin{gathered}
d=\text { Cohen's } d=\frac{M_{E}-M_{C}}{\sqrt{\frac{\left(N_{E}-1\right) S D_{F}^{2}+\left(N_{E}-1\right) S D_{C}^{2}}{N_{E}-N_{C}-2}}} \\
g=\text { Hedges' } g=d \times\left(1-\frac{3}{4\left(N_{E}+N_{C}-2\right)-1}\right)
\end{gathered}
$$

The equation to calculate the standard error and confidence interval (CI) for Hedges' $\mathrm{g}$ is as follows: 


$$
S E_{g}=\left(1-\frac{3}{4\left(N_{E}+N_{C}-2\right)-1}\right) * \sqrt{\frac{N_{E}+N_{C}}{N_{E} * N_{C}}+\frac{d^{2}}{2\left(N_{E}+N_{C}\right)}}
$$

Note. $M_{E}$ and $M_{C}$ represent the mean of the learning performance of the experimental group and the control group respectively. $N_{E}$ and $N_{C}$ represent the sample size of the experimental group and the control group respectively. $S D_{E}$ and $S D_{C}$ represent the standard deviation of the experimental group and the control group respectively.

\subsection{Quality Assessment and Heterogeneity Test}

Meta-analysis is a quantitative method for comprehensive analysis of published research results (Hedges \& Olkin, 1985). Therefore, the articles included in the analysis will have a great impact on the results. To ensure the reliability of the 63 papers included in the meta-analysis, the Begg's rank correlation method and funnel plot were used to comprehensively measure the publication bias of the 63 sample articles. The funnel plot allows people to visually judge the publication bias, while the Begg's rank correlation method complements the funnel plot from a quantitative perspective. If $\mathrm{Z}>1.96, p<0.05$, there may be a publication bias; $Z<1.96, p>0.05$ indicates no publication bias (Begg \& Mazumdar, 1995). As depicted in Figure 2, the effect size of the study sample was evenly distributed on both sides of the average effect size, and most were distributed within the confidence interval. In addition, the results of Begg's test showed that $\mathrm{Z}=$ $0.51<1.96$ and $p=0.607>0.05$. Thus, there was no publication bias in the sample literature.

Heterogeneity refers to the inconsistencies in research results among samples. I-squared (I2) and Q-statistic can measure the heterogeneity in meta-analysis. STATA 12.0 was used to test the heterogeneity of the 63 sample papers, and the result was $\mathrm{I} 2=92 \%>50 \%$, so it shows a high level of heterogeneity (Higgins \&

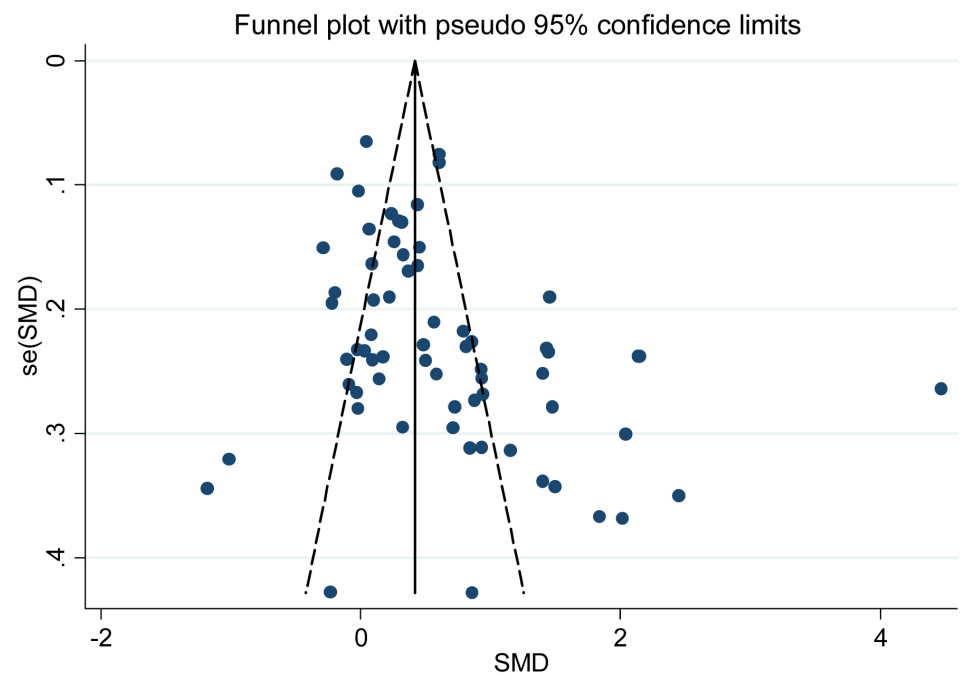

Figure 2. Funnel plot of inclusion of the 63 studies $(k=66)$. NOTE. SMD: standard mean difference, calculated by Hedges'g; se: standard error. 
Thompson, 2002). Therefore, the random effect model was adopted for metaanalysis in the present study. The Q-statistic test is a test of the null hypothesis that all studies in the meta-analysis have an identical effect size (Borenstein et al., 2010). In this study, the $q$-value is 815.48 with 65 degrees of freedom and a $p$-value of $0.00<0.001$. Thus, we can reject the null hypothesis that the true effect size is common in all the studies (Borenstein et al., 2010). Therefore, except for the sampling error, there may be several other moderators that result in heterogeneity (Borenstein et al., 2010). Therefore, subgroup analysis was also performed to determine their impact size. These moderating variables are: 1) study design, 2) sample size, 3) learning stage, 4) subject area, 5) knowledge type, 6) instructor equivalence, and 7) intervention duration of the flipped classroom.

\section{Results and Discussion}

\subsection{Descriptive Statistics Information}

The total sample size of students who experienced flipped classrooms $(N=4716)$ and traditional classrooms $(N=4447)$ is $N=9163$ (Table A1 of the Appendix). Figure 3 is a descriptive chart of the sample papers. As shown in Figure 3, about half of the experiments were performed using a two-group pretest-posttest design. About $68.18 \%$ of the experiments were implemented for more than 10 weeks, and most of them lasted for one semester. At the same time, for the purpose of reducing the influence of teacher differences on the experimental results, $80.30 \%$ of the experiments ensured that the experimental group had the same teacher as the control group. The learning stage of the participants covered elementary school, middle school, high school and university, $83.33 \%$ of which

Descriptive statistics of the 63 papers $(\mathrm{K}=66)$ included in the meta-analysis

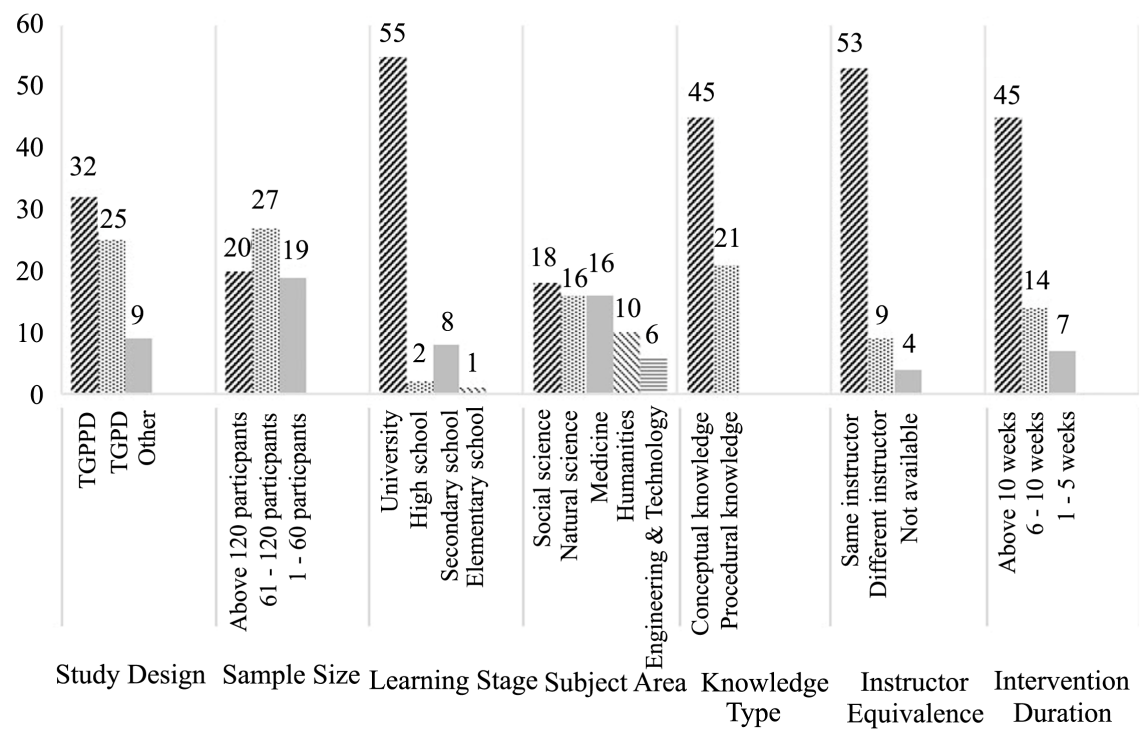

Figure 3. Descriptive statistics of 63 papers included in the meta-analysis. Note. TGPPD: two group pretest posttest design; TGPD: two group posttest design; CK: conceptual knowledge; PK: procedural knowledge; $\mathrm{k}$ : the number of effect size. 
took place in higher education, and the number of participants in the experiment was generally more than 60 . The sample literature covers a wide range of subject areas, while the papers relating to humanities and engineering techniques are relatively few. This phenomenon is the same as that reported by Cheng et al. (2019). Most of the course knowledge selected in the experiment was conceptual knowledge.

\subsection{Overall Effect Size of the Flipped Classroom for Learning Performance}

Figure 4 depicts the effect size and confidence interval for each of the 63 studies, and the average effect size of all studies. Each small box in the figure corresponds to the effect size of each study, and the horizontal line through each small box signifies the confidence interval. The vertical solid line in the middle is an invalid line, indicating that the factors studied are not statistically related to the outcome. The diamond at the bottom of the forest plot, which is crossed by a dotted line, describes the combined effect size and its confidence interval. As shown in Figure 4, most studies were on the right side of the invalid line, with statistical significance. Cohen (1988) believes that when the effect size is greater than 0.8 , it can be considered large; it is medium between 0.2 and 0.8 , and less than 0.2 is small and has little significant meaning. In the sample literature, the effect size of 22 studies was less than 0.2 , which was a small effect, and the effect size of 20 studies was between 0.2 and 0.8 , which was a medium effect. A total of 24 studies have an impact greater than 0.8 , which suggests that the flipped classroom can obviously promote students' learning performance. However, the calculation results show that the average effect size of the 63 studies is $0.621(95 \%$ confidence interval, $\mathrm{CI}=0.464-0.778, \mathrm{Z}=7.74, p<0.001), 0.2 \leq 0.621 \leq 0.8$, so it is a medium effect size. Finally, the result of Rosenthal's fail-safe $\mathrm{N}$ test determined that 16,585 additional studies with null results would be required to nullify the current overall effect size (Rosenthal, 1979). Therefore, the flipped classroom instructional mode can improve students' learning performance. This conclusion is the same as those of Lag and Saele (2019) and Cheng et al. (2019).

\subsection{Effect Sizes of Academic Achievement by Moderator Variables}

For the purpose of investigating the impact of flipped classrooms on student academic achievement in different contexts, several moderator variables were analyzed using the random-effect model by STATA, and the results are shown in Table 1. As shown in Table 1, the heterogeneity between subgroups was large, and the source of heterogeneity could not be found. To evaluate the statistical stability of the results, every study was excluded from the meta-analysis each time to reveal the effect of every dataset on the merged pooled results. Through sensitivity analysis, the result showed that the study of Kim and Jang (2017) had the greatest impact on the total merger effect. If this study was removed, the overall effect had a great impact, but it was still within 95\% CI. After carefully reading the research of Kim and Jang (2017), we found that the effect size of this 
Anderson et al. (2017)

Asiksoy and Ozdamli (2016)

Asiksoy and Ozdamli (2017)

Balaban et al. (2016)

Burgoyne and Eaton (2018)

Burnham and Mascenik (2018)

Cabi (2018)

Chao et al. (2015)

Chis et al. (2018)

Chiu et al. (2017)

Cho et al. (2018)

Choi and Lee (2018)

Chutinan et al. (2018)

Chyr et al. (2017)

Cruzado and Roman (2015)

Davies et al. (2013)

Day (2018)

Ekmekci (2017)

Elian and Hamaidi (2018)

Elmaadaway (2018)

Fadol et al. (2018)

Fleagle et al. (2017)

Goff et al. (2018)

Harrington et al. (2015)

Hotle and Garrow (2016)

Jong (2017)

Khan and Watson (2018)

Kim, H. R. et al. (2017)

Kim, J. E. et al. (2017)

Kostaris et al. (2017)

Kurt (2017)

Leis et al. (2015)

Lento (2016)

Lin and Hwang (2018)

Lin et al. (2018)

Liou et al. (2016)

Lo et al. (2018)

Lo et al. (2018)

Lo et al. (2018)

Lo et al. (2018)

Lucchetti et al. (2018)

Mason et al. (2013)

Mattis (2014)

McCabe et al. (2017)

Missildine et al. (2013)

Moraros et al. (2015)

Muzyk et al. (2015)

Nakanishi et al. (2017)

Olakanmi (2016)

Olitsky and Cosgrove (2016)

Sengel (2014)

Sengel (2016)

Sezer (2017)

Shiau et al. (2018)

Smallhorn (2017)

Sommer and Ritzhaupt (2018)

Sun and Wu (2016)

Thai et al. (2017)

Tusa et al. (2018)

Wang, J. et al. (2018)

Wang, J. Y.et al. (2018)

Wasserman et al. (2017)

Yu and Wang (2016)

Zhu and Xie (2018)

Zhu, Y. C. et al. (2018)

Zupanec et al. (2018)

Overall (I-squared $=92.0 \%, p=0.000)$

NOTE: Weights are from random effects analysis

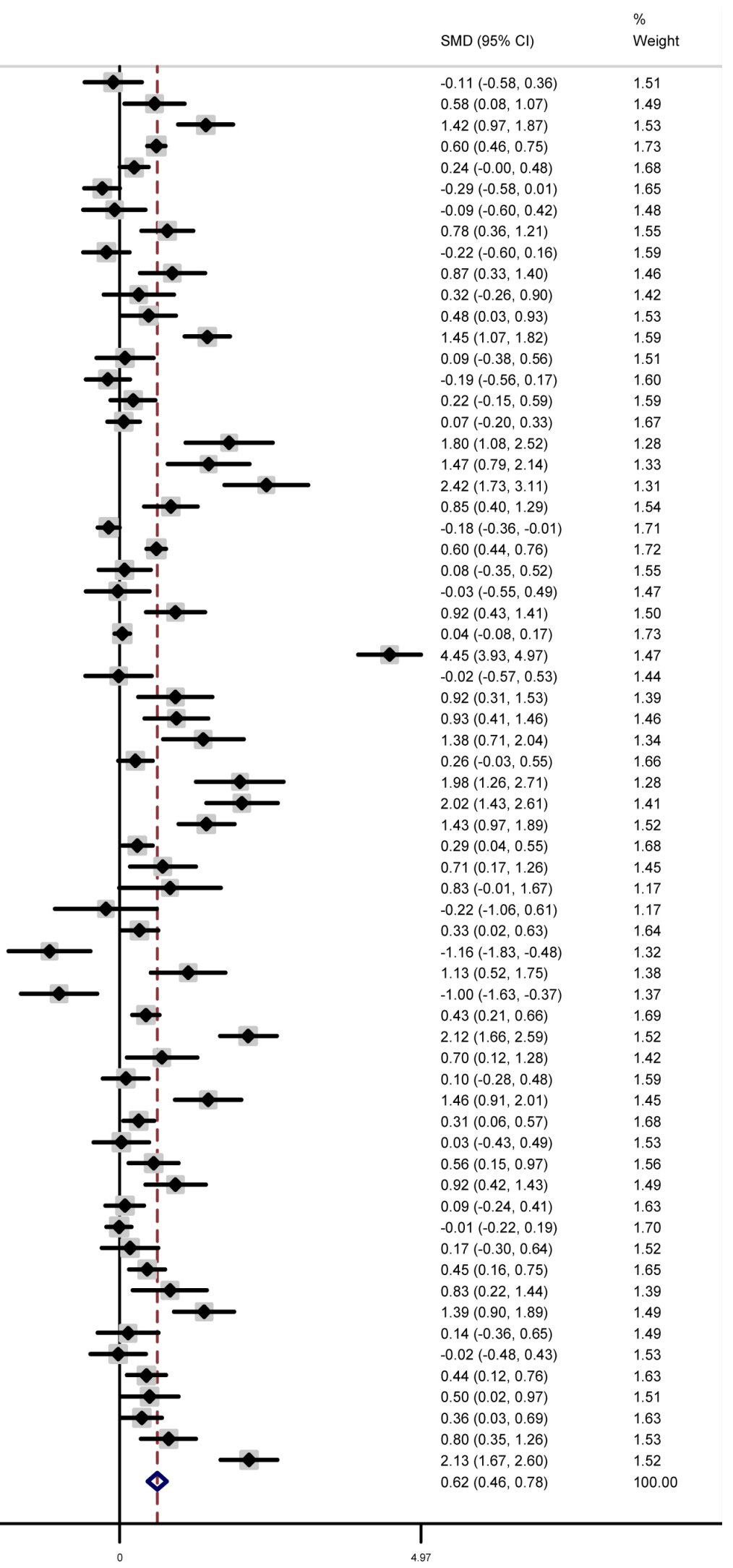

Figure 4. Forest plot of the 63 papers $(k=66)$. Note. CI: confidence interval; SMD: standard mean difference, calculated by Hedges' g. 
Table 1. Meta-analysis according to moderator variables.

\begin{tabular}{|c|c|c|c|c|c|c|c|c|c|c|}
\hline \multirow{2}{*}{\multicolumn{2}{|c|}{ Moderator variables }} & \multirow{2}{*}{$\begin{array}{c}\text { Sample } \\
\text { size } \\
(N=9163)\end{array}$} & \multirow{2}{*}{$\begin{array}{c}\text { Number of } \\
\text { effect sizes } \\
(k=66)\end{array}$} & \multicolumn{4}{|c|}{ Effect size and $95 \%$ confidence interval } & \multicolumn{3}{|c|}{ Heterogeneity } \\
\hline & & & & Effect size $(g)$ & Lower limit & Upper limit & $p$ & I-squared, \% & Q-statistic & $p$ \\
\hline \multirow{3}{*}{$\begin{array}{l}\text { Study } \\
\text { Design }\end{array}$} & TGPPD & 2746 & 32 & 0.858 & 0.524 & 1.911 & $<0.001$ & 93.9 & 510.54 & $<0.001$ \\
\hline & TGPD & 5023 & 25 & 0.467 & 0.259 & 0.638 & $<0.001$ & 83.7 & 188.27 & $<0.001$ \\
\hline & Other & 1394 & 9 & 0.174 & -0.053 & 0.401 & 0.132 & 73.2 & 29.81 & $<0.001$ \\
\hline \multirow{3}{*}{$\begin{array}{l}\text { Sample } \\
\text { Size }\end{array}$} & $1-60$ & 888 & 19 & 0.668 & 0.267 & 1.07 & 0.001 & 87.3 & 141.94 & $<0.001$ \\
\hline & $61-120$ & 2224 & 27 & 0.724 & 0.467 & 0.982 & $<0.001$ & 82.2 & 221.26 & $<0.001$ \\
\hline & Above 120 & 6051 & 20 & 0.455 & 0.213 & 0.698 & $<0.001$ & 95.2 & 395.24 & $<0.001$ \\
\hline \multirow{4}{*}{$\begin{array}{l}\text { Learning } \\
\text { Stage }\end{array}$} & Primary school & 112 & 1 & 2.132 & 1.665 & 2.599 & $<0.001$ & 0 & 0 & $<0.001$ \\
\hline & Secondary school & 597 & 8 & 0.745 & 0.404 & 1.085 & $<0.001$ & 70.3 & 23.54 & 0.001 \\
\hline & High school & 165 & 2 & 0.384 & -0.405 & 1.173 & 0.34 & 84.3 & 6.38 & 0.012 \\
\hline & University & 8289 & 55 & 0.586 & 0.415 & 0.757 & $<0.001$ & 92.6 & 725.06 & $<0.001$ \\
\hline \multirow{5}{*}{$\begin{array}{l}\text { Subject } \\
\text { Area }\end{array}$} & Social science & 3342 & 18 & 0.579 & 0.367 & 0.79 & $<0.001$ & 87 & 130.64 & $<0.001$ \\
\hline & Natural science & 2343 & 16 & 0.67 & 0.415 & 0.925 & $<0.001$ & 86.5 & 111.01 & $<0.001$ \\
\hline & Medicine & 2458 & 16 & 0.648 & 0.181 & 1.114 & 0.006 & 96.6 & 435.27 & $<0.001$ \\
\hline & Humanities & 545 & 10 & 1.024 & 0.576 & 1.473 & $<0.001$ & 82.9 & 52.27 & $<0.001$ \\
\hline & $\begin{array}{l}\text { Engineering } \\
\text { \&Technology }\end{array}$ & 475 & 6 & -0.118 & -0.551 & 0.315 & 0.593 & 81 & 26.28 & $<0.001$ \\
\hline \multirow{2}{*}{$\begin{array}{c}\text { Knowledge } \\
\text { Type }\end{array}$} & $\begin{array}{l}\text { Conceptual } \\
\text { knowledge }\end{array}$ & 6848 & 45 & 0.621 & 0.464 & 0.778 & $<0.001$ & 95.6 & 456.72 & $<0.001$ \\
\hline & $\begin{array}{l}\text { Procedural } \\
\text { knowledge }\end{array}$ & 2315 & 21 & 0.696 & 0.266 & 1.127 & 0.002 & 87.6 & 357.73 & $<0.001$ \\
\hline \multirow{3}{*}{$\begin{array}{l}\text { Instructor } \\
\text { Equivalence }\end{array}$} & Same instructor & 6859 & 53 & 0.72 & 0.527 & 0.913 & $<0.001$ & 92.9 & 729.74 & $<0.001$ \\
\hline & $\begin{array}{l}\text { Different } \\
\text { instructor }\end{array}$ & 1697 & 9 & 0.346 & 0.188 & 0.504 & $<0.001$ & 51.4 & 16.46 & 0.036 \\
\hline & Not available & 607 & 4 & 0.11 & -0.774 & 0.998 & 0.808 & 95.2 & 61.93 & $<0.001$ \\
\hline \multirow{3}{*}{$\begin{array}{l}\text { Intervention } \\
\text { Duration }\end{array}$} & $1-5$ weeks & 590 & 7 & 0.632 & 0.205 & 1.059 & 0.004 & 84.1 & 44.08 & $<0.001$ \\
\hline & 6 - 10 weeks & 1291 & 14 & 1.199 & 0.544 & 1.854 & $<0.001$ & 96.3 & 352.21 & $<0.001$ \\
\hline & Above 10 weeks & 7282 & 45 & 0.441 & 0.297 & 0.584 & $<0.001$ & 87.7 & 349.39 & $<0.001$ \\
\hline
\end{tabular}

Note. TGPPD: two group pretest posttest design; TGPD: two group posttest design.

research is significantly larger $(g=4.452)$ than those of other research. Kim and Jang (2017) designed a randomized, controlled trial to assess the impact of a flipped classroom on nursing students at a university in South Korea, and two separate experiments were implemented in two different years to prevent diffusion and imitation effects between the control and the experimental groups. Most of the other 62 studies included in the meta-analysis focused on naturally occurring classes in schools, and rarely separated the experimental group from the control group by 2 years, so the study design may be one of the sources of heterogeneity. Due to the characteristics of nursing education, each class inter- 
vention lasted 100 minutes. Students' academic performance was also included in the assessment of learning content and practical performance, so different regions, schools' teaching methods and evaluation methods may have caused the heterogeneity

\subsubsection{Study Design and Sample Size}

As can be seen from Table 1, 32 studies ( $N=2746$ participants, $g=0.858>0.8$, $p<0.001)$ adopted the experiment design of two group pretest-posttest, and 25 studies $(N=5023, g=0.467, p<0.001)$ adopted the experiment design of two group posttest. The remaining nine groups of experiments had an effect size of 0.174 , but $p=0.132$, so these results were not statistically significant. The effect sizes of the two group pretest-posttest $(g=0.858)$, the two-group post-test $(g=$ $0.467)$, and other experimental designs $(g=0.174)$ are three levels: large, medium and small, respectively. The effect size of the studies with the sample size of 61-120 ( $g=0.724, k=27, N=2224)$ is higher than the sample size of 120 ( $g=$ $0.455, k=20, N=6051)$ and the sample size below $60(g=0.668, k=19, N=$ 888). Thus, under the different study designs and sample sizes, the impact of flipping classrooms on students' learning performance differs.

In the four studies of "other" (Chis, Moldovan, Murphy, Pathak, \& Muntean, 2018; Chyr, Shen, Chiang, Lin, \& Tsia, 2017; Fleagle, Borcherding, Harris, \& Hoffmann, 2017; Wang, Jou, Lv, \& Huang, 2018a), the experimental group and control group were not set in the same semester, but adopted the design of a control class in the previous semester and an experimental group in the current semester. The effect sizes of these four studies are $-0.184,0.089,-0.023$ and -0.218 respectively (Table A1 of the Appendix). The flipped classroom does not have a great advantage in these four groups of samples. Wasserman, Quint, Norris, and Carr (2017) suggest that this study design may not control some unrelated variables well. Even if the teacher of the control and trial group is the same, the teaching ability and experience of the teachers will improve with time. Therefore, in the future experimental design, the experimental group and the control group should be controlled in the same time period for better control variables, while also paying attention to the diffusion and imitation effect of the experimental and control groups (Kim \& Jang, 2017).

\subsubsection{Learning Stage}

As can be gleaned from Table 1, among the selected research samples, the experiments in the flipped classroom mainly targeted students at university $(N=8289$, $k=55)$, followed by secondary school $(N=597, k=8)$, high school $(N=165, k=$ $2)$, and elementary school $(N=112, k=1)$. The effect size of university $(g=$ $0.586)$, secondary school $(g=0.745)$ and high school $(g=0.384)$ is medium, and the elementary school $(g=2.132)$ is large, but there was only one experiment in elementary school. The effect sizes of the students from the four learning stages are all greater than zero, indicating that students who experienced the flipped classroom had better learning performance than those who experienced the tra- 
ditional classroom. However, the $p$-value of the high school stage experiment was 0.34 and the confidence interval included zero, which was not statistically significant for us.

Most of the empirical research on flipped classrooms was carried out in the higher education stage. This result is consistent with Cheng et al. (2019) and Tucker (2013). The flipped classroom is mainly used in the field of higher education to innovate the conventional teaching model, and it is also attracting increasing attention at the K-12 stage (Johnson et al., 2013; Tucker, 2013). Most of the researchers are from higher education institutions where they collect data easily from university. On the other hand, some students think it is not suitable to carry out flipped classrooms in lower grades, because the students in lower grades may not have the academic maturity needed to be successful in the flipped setting, or may have a lower level of flipped classroom preparation, with half of the students who experienced the flipped class saying they would not choose another flipped class (Mason, Shuman, \& Cook, 2013; Strayer, 2007; Tomas, Evans, Doyle, \& Skamp, 2019). The flipped classroom has higher requirements on student's self-regulated learning activities than the traditional classroom, and students' self-regulated learning abilities affect the effectiveness of flipped classrooms (Rodrigues, Sedraz, Ramos, de Souza, \& Gomes, 2016). Moreover, the design of flipped courses is dependent on online resources; the more students watch the course website, the higher the test score they will acquire (Hotle \& Garrow, 2016). In fact, if there is a lack of supervision, students often procrastinate or just open a video file without understanding the content (Beatty, Merchant, \& Albert, 2019). In this condition, teachers need to reinforce interaction with students or assign assistants to supervise them; that is, they can conduct flipped learning on a continuum that develops different levels of student-oriented learning and autonomy based on students' learning needs and their preparation for the flipped classroom (Beatty et al., 2019; Sun \& Wu, 2016; Tomas et al., 2019).

\subsubsection{Subject Area and Knowledge Type}

Table 1 shows the subgroup analysis by subject area and knowledge type for the flipped classroom versus conventional classroom. The flipped classroom was used in various professional fields, but the humanities $(k=10, N=545)$ and engineering sciences $(k=6, N=475)$ are relatively small compared to the social sciences ( $k=19, N=3342)$, natural sciences $(k=16, N=2343)$, and medicine (k $=16, N=2458)$. The social sciences $(g=0.579)$, natural sciences $(g=0.67)$, and medicine $(g=0.648)$ have moderate effect sizes, and the humanities has the largest effect size $(g=1.024)$, while the effect size of engineering and technology is -0.118 . Therefore, in the five subject areas, except for engineering and technology, students performed better in the flipped classrooms than in traditional classrooms. The $p$-value of engineering and technology is 0.593 , indicating that this is not statistically significant for this condition. Humanities $(p<0.001)$ show great results for the flipped classroom teaching method, with 10 groups of expe- 
riments included in the humanities classification, most of which are associated with language learning. Five groups are English (Ekmekci, 2017; Lin \& Hwang, 2018; Lin, Hwang, Fu, \& Chen, 2018; Yu \& Wang, 2016), two are Chinese (Wang, An, \& Wright, 2018b; Lo et al., 2018), and one is Korean (Kim, Park, Jang, \& Nam, 2017). Only the effect size of Kim et al. (2017) is -0.018 , indicating that the student outcomes in the traditional classroom were better than those in the flipped classroom. Therefore, the flipped classroom instructional strategy may be suitable for language learning. From the perspective of knowledge type, conceptual knowledge ( $g=0.621)$ and procedural knowledge $(g=0.696)$ have moderate effects, and students perform better in flipped classrooms than in traditional classrooms, while the difference between the two types of knowledge is not obvious. After the experiment, there is also no difference between flipped classrooms and traditional classrooms in the retention of knowledge type (Bouwmeester et al., 2019).

Not all course materials are fit for students to learn autonomously by instructional videos (Scott, Green, \& Etheridge, 2016). Braun, Ritter and Vasko (2014) also found that the flipped classroom method may not be applicable to all topics. However, classroom presentation of new knowledge and problem-based teaching did not receive enough attention in some flipped classrooms. In some studies (e.g., Bhagat, Chang, \& Chang, 2016; Kostaris, Sergis, Sampson, Giannakos, \& Pelliccione, 2017), teachers used the instructional video to invert the classroom completely, leaving only a little and new content for the classroom. However, some topics are easy to understand through video, whereas others are too complex for students to learn (Scott et al., 2016). Even if some students watch the video repeatedly, they still cannot understand the knowledge presented in the video course. Therefore, during the experimental intervention, the teacher had to spend extra classroom time going over the concepts. To overcome this cognitive impairment, the classroom duration of the flipped model was extended from 50 minutes to 100 minutes/day; however, it caused overload for the students and teachers (Anderson et al., 2017; Bouwmeester et al., 2019).

\subsubsection{Instructor Equivalence and the Duration of Intervention}

As depicted in Table 1, in 53 studies, the control group had the same teacher as the experimental group, while in nine studies the two groups had different teachers. Whether it is the same or a different teacher, the students' learning performance in the flipped classroom is better than in the regular class, but the effect size of the same teacher $(g=0.72)$ is greater than that of different teachers $(g=$ 0.346 ). Therefore, teachers have little influence on students, but two different instructors may lead to an instructor bias (Webster \& Majerich, 2014). Therefore, in future experiments, researchers should ensure that the teachers in the experimental group are consistent with those in the control group. From the duration of the experiment, the effect of the experimental intervention time of $6-10$ weeks $(N=1291, g=1.199)$ is better than that of $1-5$ weeks $(N=590, g=0.632)$ and above 10 weeks $(N=7282, g=0.441)$. There were 45 studies with one seme- 
ster as the experimental time, but the effect was not as good as that for 6 - 10 weeks. Most of the experiments of 1 - 5 weeks were based on unit learning. Students' learning in the flipped classroom was better than in the traditional classroom, but the $p$-value was 0.004 , which indicates that it is not statistically significant in this case.

The effect size of medium intervention duration was found to be the largest. Anderson et al. (2017) also found a small to moderate effect of flipped classrooms on students' performance after intervention of about 6 months, although long-term gains failed to reach statistical significance. If the intervention time of the flipped classroom is too short, students may not quickly adapt to this teaching method. Some studies (e.g., Hotle \& Garrow, 2016; Mason et al., 2013) concluded that when a flipped classroom is implemented, students usually have an adaptation period of about 3 weeks. When they realize that their original learning habits are inconsistent with the current learning mode, they will self-adjust their learning habits. In the first few weeks of the course, students who experienced flipped classes spent the same amount of time on homework activities as the students who experienced traditional classes, and spent less time than the students who experienced traditional classes in a week before the final examination (Bouwmeester et al., 2019). On the other hand, students who learned in a flipped classroom spent more time on homework activities on average than students in a traditional classroom (Bouwmeester et al., 2019). In order to minimize the extra workload bias, Blazquez et al. (2019) reduced the time spent in the flipped classroom by 2 hours, but the score of the experimental group was lower than that of the control group during the short-term intervention, while there was no significant difference in the learning effect of the two groups in the long-term intervention. In addition, the flipped class session was too short, and the students did not have enough time for in-depth discussion. However, extending the class time will increase students' learning load, and even reduce the self-efficacy of the students who experienced the flipped classroom to the same level as the students in the traditional classroom at the end of the course (Bouwmeester et al., 2019; Rodriguez et al., 2019).

\section{Conclusion}

In this meta-analysis, we identified and extracted the eligible papers in the core collection of the Web of Science database, then encoded and analyzed 63 papers included in the meta-analysis. The overall impact of flipped and traditional classrooms on student academic achievement was analyzed using STATA (Version 12.0). According to the results of the analysis, the present study found that students' performance in flipped classrooms was better than in traditional classrooms, with a 0.621 average effect size. It proved the flipped classroom instructional strategy can effectively improve students' learning performance. The first question was answered.

The results of this study indicated that learning outcomes varied with specific 
characteristics such as study design, sample size, learning stage, subject area, knowledge type, instructor equivalence and intervention duration. The second question was answered. 1) Study design: through the analysis of the moderator variables, the study found that the experimental results of the two group pretest-posttest design were better than those of the two group posttest design; 2) Sample size: the experimental results of samples below 120 were better than those of the large sample size (greater than 120); 3) Learning stage: flipped classrooms have been applied in K-12 education and higher education, but according to the number of studies, flipped classrooms are more commonly applied in higher education. The impact of the high school stage is lower than that of the elementary school, junior high school, and university stages; 4) Subject area: the flipped classroom teaching effect in the humanities is better than that in the social sciences, natural sciences, and medical education, while the students of engineering education perform better in traditional classrooms; 5) Knowledge type: the influence of knowledge types on the effect of flipping classroom learning is not obvious; 6) Instructor equivalence: the experimental results of the same teachers were better than those of different teachers; 7) Intervention duration: short-term and medium-term interventions are better than long-term interventions (more than 10 weeks).

\subsection{Implications}

When implementing flipped classrooms, teachers have to consider whether students can adapt to and accept the curriculum reform and whether the content is suitable for a flipped classroom. The conclusions of this study provide a broad perspective for relevant researchers and educators to study or implement flipped classrooms. Teachers should consider the number of the students according to the sample size (the sample below 120 were better than larger sample), learning stage (higher education is better than K12), subject area (the subject of humanities is better), and intervention duration (short-term and medium-term interventions are better).

\subsection{Research Limitations and Future Research}

This meta-analysis has a large heterogeneity in terms of both total analysis and subgroup analysis, like the study of Xu et al. (2019). This phenomenon may be caused by the following factors: 1 ) the different evaluation methods of students' learning performance; 2) different cases of flipped instruction in schools have different teaching objectives, different content, and different teaching methods in the implementation of the flipped classroom. This study collected as much of the eligible literature as possible in the core collection of the Web of Science database, but there would be more articles if it was also searched in other databases to obtain the target literature. In this study, only one study conducted in elementary school and two studies conducted in high school were found. Therefore, whether the implementation of flipped classrooms in elementary and high 
schools is effective, it remains to be further explored. In the process of coding the articles, most empirical research on the flipped classroom only discussed the students' learning performance, with few papers also discussing the students' learning motivation and learning attitude. In addition, most of the research describes the experimental process and the posttest score, but there is no specific description of the learning materials and the implementation process of the flipped classroom. Therefore, it is difficult to determine whether these factors have an important influence on the students' learning performance.

Future research on flipped classrooms can also explore the effects on students' outcomes including type of learning resources provided by teachers before class, the length or style of videos, whether tests are provided before class, and the form of teacher-student interaction in class. In flipped classrooms, students play the main role while teachers play the secondary role. However, the transfer of learning responsibility makes students feel that the workload is too heavy, which is also a great challenge for teachers. How to reduce the burden on students and teachers is a problem worth paying attention to in further studies.

\section{Acknowledgements}

This research was supported by a grant from the Priority Academic Program Development of Jiangsu Higher Education Institutions in China.

\section{Authors' Contributions}

This work is the result of the collaboration of all authors. All authors have equally contributed, reviewed, and improved the manuscript. All authors have revised and approved the final manuscript.

\section{Conflicts of Interest}

The authors declare that they have no conflict of interest.

\section{References}

Alamri, M. M. (2019). Students' Academic Achievement Performance and Satisfaction in a Flipped Classroom in Saudi Arabia. International Journal of Technology Enhanced Learning, 11, 103-119. https://doi.org/10.1504/IJTEL.2019.096786

Anderson, H. G. J., Frazier, L., Anderson, S. L., Stanton, R., Gillette, C., Broedel-Zaugg, K., \& Yingling, K. (2017). Comparison of Pharmaceutical Calculations Learning Outcomes Achieved within a Traditional Lecture or Flipped Classroom Andragogy. American Journal of Pharmaceutical Education, 81, 70. https://doi.org/10.5688/ajpe81470

Ang, A., Zaid, N. M., \& Harun, J. (2015). A Meta-Analysis on Students' Social Collaborative Knowledge Construction Using Flipped Classroom Model. IEEE Conference on eLearning, e-Management and e-Services (IC3e), Melaka, 24-26 August 2015, 58-63.

Asiksoy, G., \& Ozdamli, F. (2016). Flipped Classroom Adapted to the ARCS Model of Motivation and Applied to a Physics Course. EURASIA Journal of Mathematics, Science \& Technology Education, 12, 1589-1603. https://doi.org/10.12973/eurasia.2016.1251a

Asiksoy, G., \& Ozdamli, F. (2017). The Flipped Classroom Approach Based on the 5E Lear- 
ning Cycle Model-5ELFA. Croatian Journal of Education, 19, 1131-1166. https://doi.org/10.15516/cje.v19i4.2564

Balaban, R. A., Gilleskie, D. B., \& Tran, U. (2016). A Quantitative Evaluation of the Flipped Classroom in a Large Lecture Principles of Economics Course. The Journal of Economic Education, 47, 269-287. https://doi.org/10.1080/00220485.2016.1213679

Beatty, B. J., Merchant, Z., \& Albert, M. (2019). Analysis of Student Use of Video in a Flipped Classroom. Tech Trends, 63, 376-385. https://doi.org/10.1007/s11528-017-0169-1

Begg, C. B., \& Mazumdar, M. (1995). Operating Characteristics of a Rank Correlation Test for Publication Bias. Biometrics, 50, 1088-1101. https://doi.org/10.2307/2533446

Bergmann, J., \& Sams, A. (2012). Flip Your Classroom: Reach Every Student in Every Class Every Day. Internal Society for Technology in Education.

Bhagat, K. K., Chang, C. N., \& Chang, C. Y. (2016). The Impact of the Flipped Classroom on Mathematics Concept Learning in High School. Journal of Educational Technology \& Society, 19, 134-142.

Blazquez, B. O., Masluk, B., Gascon, S., Diaz, R. F., Aguilar-Latorre, A., Magallon, I. A., \& Botaya, R. M. (2019). The Use of Flipped Classroom as an Active Learning Approach Improves Academic Performance in Social Work: A Randomized Trial in a University. PLoS ONE, 14, e0214623. https://doi.org/10.1371/journal.pone.0214623

Borenstein, M., Hedges, L. V., Higgins, J. P. T., \& Rothstein, H. R. (2010). A Basic Introduction to Fixed-Effect and Random-Effects Models for Meta-Analysis. Research Synthesis Methods, 1, 97-111. https://doi.org/10.1002/jrsm.12

Bouwmeester, R. A. M., de Kleijn, R. A. M., van den Berg, I. E.T., ten Cate, O. T. J., van Rijen, H. V. M., \& Westerveld, H. E. (2019). Flipping the Medical Classroom: Effect on Workload, Interactivity, Motivation and Retention of Knowledge. Computer \& Science, 139, 118-128. https://doi.org/10.1016/j.compedu.2019.05.002

Braun, I., Ritter, S., \& Vasko, M. (2014). Inverted Classroom by Topic: A Study in Mathematics for Electrical Engineering Students. International Journal of Engineering Pedagogy, 4, 11-17. https://doi.org/10.3991/ijep.v4i3.3299

Burgoyne, S., \& Eaton, J. (2018). The Partially Flipped Classroom: The Effects of Flipping a Module on "Junk Science" in a Large Methods Course. Teaching of Psychology, 45, 154157. https://doi.org/10.1177/0098628318762894

Burnham, K. D., \& Mascenik, J. (2018). Comparison of Student Performance and Perceptions of a Traditional Lecture Course versus an Inverted Classroom Format for Clinical Microbiology. Journal of Chiropractic Education, 32, 90-97. https://doi.org/10.7899/JCE-17-21

Cabi, E. (2018). The Impact of the Flipped Classroom Model on Students' Academic Achievement. The International Review of Research in Open and Distributed Learning, 19, 202221. https://doi.org/10.19173/irrodl.v19i3.3482

Chao, C. Y., Chen, Y. T., \& Chuang, K. Y. (2015). Exploring Students Learning Attitude and Achievement in Flipped Learning Supported Computer Aided Design Curriculum: A Study in High School Engineering Education. Computer Applications in Engineering Education, 23, 514-526. https://doi.org/10.1002/cae.21622

Chen, K. S., Monrouxe, L., Lu, Y. H., Jenq, C.C., Chang, Y. J., Chang, Y.C., \& Chai, P. Y. C. (2018). Academic Outcomes of Flipped Classroom Learning: A Meta-Analysis. Medical Education, 52, 910-924. https://doi.org/10.1111/medu.13616

Cheng, L., Ritzhaupt, A. D., \& Antonenko, P. (2019). Effects of the Flipped Classroom Instructional Strategy on Students' Learning Outcomes: A Meta-Analysis. Educational Tech- 
nology Research and Development, 67, 793-824.

https://doi.org/10.1007/s11423-018-9633-7

Chis, A. E., Moldovan, A. N., Murphy, L., Pathak, P., \& Muntean, C. H. (2018). Investigating Flipped Classroom and Problem-Based Learning in a Programming Module for Computing Conversion Course. Educational Technology \& Society, 21, 232-247.

Chiu, H. Y., Kang, Y. N., Wang, W. L., Huang, H. C., Wu, C. C., Hsu, W., Tong, Y. S., \& Wei, P. L. (2017). The Effectiveness of a Simulation-Based Flipped Classroom in the Acquisition of Laparoscopic Suturing Skills in Medical Students: A Pilot Study. Journal of Surgical Education, 75, 326-332. https://doi.org/10.1016/j.jsurg.2017.07.007

Cho, H., Osborne, C., Sonders, T., \& Park, K. (2015). Multidimensional Teaching: Thoughtful Ways of Creating a Flipped Classroom. Korean Journal of Mathematics, 23, 93-114. https://doi.org/10.1016/j.jsurg.2017.07.007

Choi, J., \& Lee, Y. (2018). To What Extent Does "Flipping” Make Lessons Effective in a Multimedia Production Class. Innovations in Education and Teaching International, 55, 3-12. https://doi.org/10.1080/14703297.2015.1123105

Chuang, H. H., Weng, C. Y., \& Chen, C. H. (2018). Which Students Benefit Most from a Flipped Classroom Approach to Language Learning. British Journal of Educational Tech nology, 49, 56-68. https://doi.org/10.1111/bjet.12530

Chutinan, S., Riedy, C. A., \& Park, S. E. (2018). Student Performance in a Flipped Classroom Dental Anatomy Course. European Journal of Dental Education, 22, e343-e349. https://doi.org/10.1111/eje.12300

Chyr, W. L., Shen, P. D., Chiang, Y. C., Lin, J. B., \& Tsia, C. W. (2017). Exploring the Effects of Online Academic Help-Seeking and Flipped Learning on Improving Students' Learning. Educational Technology \& Society, 20, 11-23.

Clark, R. C., Nguyen, F., \& Sweller, J. (2006). Efficiency in Learning: Evidence-Based Guidelines to Manage Cognitive Load (p. 27). Wiley. https://doi.org/10.1002/pfi.4930450920

Cohen, J. (1988). Statistical Power Analysis for the Behavioral Sciences (2nd ed.). Erlbaum.

Cooper, H., Hedges, L. V., \& Valentine, J. C. (2009). The Handbook of Research Synthesis and Meta-Analysis (pp. 226-235). Russell Sage Foundation.

Cruzado, I., \& Roman E. M. (2015). Inverted Classroom and Its Influence on Students' Attitudes across Learning Styles. Transportation Research Board, 2480, 38-44.

https://doi.org/10.3141/2480-05

Davies, R. S., Dean, D. L., \& Ball, N. (2013). Flipping the Classroom and Instructional Technology Integration in a College-Level Information Systems Spreadsheet Course. Educational Technology Research and Development, 61, 563-580. https://doi.org/10.1007/s11423-013-9305-6

Day, L. J. (2018). A Gross Anatomy Flipped Classroom Effects Performance, Retention, and Higher-Level Thinking in Lower Performing Students: Flipped Anatomy Effects Lower Performing Students. Anatomical Sciences Education, 11, 565-574. https://doi.org/10.1002/ase.1772

Ekmekci, E. (2017). The Flipped Writing Classroom in Turkish EFL Context: A Comparative study On a New Model. Turkish Online Journal of Distance Education, 18, 18-20. https://doi.org/10.17718/tojde.306566

Elian, S. A., \& Hamaidi, D. A. (2018). The Effect of Using Flipped Classroom Strategy on the Academic Achievement of Fourth Grade Students in Jordan. International Journal of Emerging Technologies in Learning, 13, 110-125.

https://doi.org/10.3991/ijet.v13i02.7816 
Elmaadaway, M. A. N. (2017). The Effects of a Flipped Classroom Approach on Class Engagement and Skill Performance in a Blackboard Course. British Journal of Educational Technology, 49, 479-491. https://doi.org/10.1111/bjet.12553

Fadol, Y., Aldamen, H., \& Saadullah, S. (2018). A Comparative Analysis of Flipped, Online and Traditional Teaching: A Case of Female Middle Eastern Management Students. The International Journal of Management Education, 16, 266-280.

https://doi.org/10.1016/j.ijme.2018.04.003

Fleagle, T. R., Borcherding, N. C., Harris, J., \& Hoffmann, D. S. (2017). Application of Flipped Classroom Pedagogy to the Human Gross Anatomy Laboratory: Student Preferences and Learning Outcomes. Anatomical Sciences Education, 11, 385-396. https://doi.org/10.1002/ase.1755

Fulton, K. (2012). Upside down and inside out: Flip Your Classroom to Improve Student Learning. Learning \& Leading with Technology, 39, 12-17.

Gillette, C., Rudolph, M., Kimble, C., Winston, N. R., Smith, L., \& Zaugg, B. K. (2018). A Meta-Analysis of Outcomes Comparing Flipped Classroom and Lecture. American Journal of Pharmaceutical Education, 82, 433-440. https://doi.org/10.5688/ajpe6898

Goff, E. E., Reindl, K. M., Christina, J., Phillip, M. C., Offerdahl, E. G., \& Schroeder, N. L. et al. (2018). Investigation of a Stand-Alone Online Learning Module for Cellular Respiration Instruction. Journal of Microbiology \& Biology Education, 19, 19.2.70. https://doi.org/10.1128/jmbe.v19i2.1460

Graham, C. R., Woodfield, W., \& Harrison, J. B. (2013). A Framework for Institutional Adoption and Implementation of Blended Learning in Higher Education. The Internet and Higher Education, 18, 4-14. https://doi.org/10.1016/j.iheduc.2012.09.003

Harrington, S. A., Bosch, M. V., Schoofs, N., Beel-Bates, C., \& Anderson, K. (2015). Quantitative Outcomes for Nursing Students in a Flipped Classroom. Nursing Education Perspectives, 36, 179-181. https://doi.org/10.5480/13-1255

Hedges, L. V., \& Olkin, I. (1985). Statistical Methods for Meta-Analysis. Academic Press.

Hew, K. F., \& Lo, C. K. (2018). Flipped Classroom Improves Student Learning in Health Professions Education: A Meta-Analysis. BMC Medical Education, 18, 38. https://doi.org/10.1186/s12909-018-1144-Z

Higgins, J. P., \& Thompson, S. G. (2002). Quantifying Heterogeneity in a Meta-Analysis. Statistics in Medicine, 21, 1539-1558. https://doi.org/10.1002/sim.1186

Hotle, S. L., \& Garrow, L. A. (2016). Effects of the Traditional and Flipped Classrooms on Undergraduate Student Opinions and Success. Journal of Professional Issues in Engineering Education and Practice, 142, Article ID: 05015005. https://doi.org/10.1061/(ASCE)EI.1943-5541.0000259

Hu, R., Gao, H., Ye, Y. S., Ni, Z. H., Jiang N., \& Jiang X. L. (2018). Effectiveness of Flipped Classrooms in Chinese Baccalaureate Nursing Education: A Meta-Analysis of Randomized Controlled Trials. International Journal of Nursing Studies, 79, 94-103. https://doi.org/10.1016/j.ijnurstu.2017.11.012

Jdaitawi, M. (2019). The Effect of Flipped Classroom Strategy on Students Learning Outcomes. International Journal of Instruction, 12, 665-680. https://doi.org/10.29333/iji.2019.12340a

Jensen, J. L., Kummer, T. A., \& Godoy, P. D. D. M. (2006). Improvements from a Flipped Classroom May Simply Be the Fruits of Active Learning. Cbe Life Sciences Education, 14, 1-12. https://doi.org/10.1187/cbe.14-08-0129

Johnson, L., Adams Becker, S., Cummins, M., Estrada, V., Freeman, A., \& Ludgate, H. (2013). NMC Horizon Report: 2013 Higher Education Edition. The New Media Consortium. 
Jong, M. S. Y. (2017). Empowering Students in the Process of Social Inquiry Learning through Flipping the Classroom. Educational Technology \& Society, 20, 306-322.

Kazanidis, I., Pellas, N., Fotaris, P., \& Tsinakos, A. (2019). Can the Flipped Classroom Model Improve Students' Academic Performance and Training Satisfaction in Higher Education Instructional Media Design Courses. British Journal of Educational Technology, 50, 2014-2027. https://doi.org/10.1111/bjet.12694

Khan, R. N., \& Watson, R. (2018). The Flipped Classroom with Tutor Support: An Experience in a Level One Statistics Unit. Journal of University Teaching \& Learning Practice, 15, Article 3. https://ro.uow.edu.au/jutlp/vol15/iss3/3

Kim, H. R., \& Jang, Y. K. (2017). Flipped Learning with Simulation in Undergraduate Nursing Education. Journal of Nursing Education, 56, 329-336.

https://doi.org/10.3928/01484834-20170518-03

Kim, J. E., Park, H., Jang, M., \& Nam, H. (2017). Exploring Flipped Classroom Effects on Second Language Learners' Cognitive Processing. Foreign Language Annals, 50, 260-284. https://doi.org/10.1111/flan.12260

Kostaris, C., Sergis, S., Sampson, D. G, Giannakos, M. N., \& Pelliccione, L. (2017). Investigating the Potential of the Flipped Classroom Model in k-12 ICT Teaching and Learning: An Action Research Study. Educational Technology \& Society, 20, 261-273.

Krathwohl, D. R. (2002). A Revision of Bloom's Taxonomy: An Overview. Theory into Practice, 41, 212-218. https://doi.org/10.1207/s15430421tip4104_2

Kurt, G. (2017). Implementing the Flipped Classroom in Teacher Education: Evidence from Turkey. Educational Technology \& Society, 20, 211-221.

Lag, T., \& Saele, R. G. (2019). Does the Flipped Classroom Improve Student Learning and Satisfaction? A Systematic Review and Meta-Analysis. AERA Open, 5, 1-17. https://doi.org/10.1177/2332858419870489

Leis, A., Cooke, S., \& Tohei, A. (2015). The Effects of Flipped Classrooms on English Composition Writing in an EFL Environment. International Journal of Computer-Assisted Language Learning and Teaching, 5, 37-51. https://doi.org/10.4018/IJCALLT.2015100103

Lento, C. (2016). Promoting Active Learning in Introductory Financial Accounting through the Flipped Classroom Design. Journal of Applied Research in Higher Education, 8, 72-87. https://doi.org/10.1108/JARHE-01-2015-0005

Lin, C. J., \& Hwang, G. J. (2018). A Learning Analytics Approach to Investigating Factors Affecting EFL Students' Oral Performance in a Flipped Classroom. Educational Technology \& Society, 21, 205-219.

Lin, C. J., Hwang, G. J., Fu, Q. K., \& Chen, J. F. (2018). A Flipped Contextual Game-Based Learning Approach to Enhancing EFL Students' English Business Writing Performance and Reflective Behaviors. Educational Technology \& Society, 21, 117-131.

Liou, W. K., Bhagat, K. K., \& Chang, C. Y. (2016). Beyond the Flipped Classroom: A Highly Interactive Cloud-Classroom (HIC) Embedded into Basic Materials Science Courses. Journal of Science Education and Technology, 25, 460-473.

https://doi.org/10.1007/s10956-016-9606-8

Lo, C. K., Lie, C. W., \& Hew, K. F. (2018). Applying “First Principles of Instruction” as a Design Theory of the Flipped Classroom: Findings from a Collective Study of Four Secondary School Subjects. Computers \& Education, 118, 150-165.

https://doi.org/10.1016/j.compedu.2017.12.003

Lucchetti, A. L. G., Ezequiel, O.D., de Oliveira, I. N., Moreira-Almeida, A., \& Lucchetti, G. (2018). Using Traditional or Flipped Classrooms to Teach "Geriatrics and Gerontolo- 
gy"? Investigating the Impact of Active Learning on Medical Students' Competences. Medical Teacher, 40, 1248-1256.

https://doi.org/10.1080/0142159X.2018.1426837

Martínez, T. S., Díaz, I. A., Rodríguez, J. M. R., \& García, A. M. R. (2019). Eficacia del Método Flipped Classroom en la Universidad: Meta-Análisis de la Producción Científica de Impacto. REICE. Revista Iberoamericana sobre Calidad, Eficacia y Cambio en Educación, 17, 25-38. https://doi.org/10.15366/reice2019.17.1.002

Mason, G. S., Shuman, T. R., \& Cook, K. E. (2013). Comparing the Effectiveness of an Inverted Classroom to a Traditional Classroom in an Upper-Division Engineering Course. IEEE Transactions on Education, 56, 430-435.

https://doi.org/10.1109/TE.2013.2249066

Mattis, K. V. (2012). The Comparative Effects of Visual-Only Instruction versus Modality Principle Instruction on Algebraic Problem Accuracy and Perceived Mental Effort at Varying Levels of Task Complexity for Undergraduate Nursing Students. Ph.D. Thesis, San Francisco: University of San Francisco.

Mattis, \& Kristina, V. (2015). Flipped Classroom versus Traditional Textbook Instruction: Assessing Accuracy and Mental Effort at Different Levels of Mathematical Complexity. Technology, Knowledge and Learning, 20, 231-248. https://doi.org/10.1007/s10758-014-9238-0

McCabe, C., Smith, M. G., \& Ferreri, S. P. (2017). Comparison of Flipped Model to Traditional Classroom Learning in a Professional Pharmacy Course. Education Sciences, 7, 73. https://doi.org/10.3390/educsci7030073

Missildine, K., Fountain, R., Summers, L., \& Gosselin, K. (2013). Flipping the Classroom to Improve Student Performance and Satisfaction. Journal of Nursing Education, 52, 597599. https://doi.org/10.3928/01484834-20130919-03

Moher, D., Liberati, A., Tetzlaff, J., Altman, D. G., \& The PRISMA Group (2009). Preferred Reporting Items for Systematic Reviews and Meta-Analyses: The PRISMA Statement. PLOS Medicine, 6, e1000097. https://doi.org/10.1371/journal.pmed.1000097

Mok, H. N. (2014). Teaching Tip: The Flipped Classroom. Journal of Information Systems Education, 25, 7-11.

Moraros, J., Islam, A., Yu, S., Banow, R., \& Schindelka, B. (2015). Flipping for Success: Evaluating the Effectiveness of a Novel Teaching Approach in a Graduate Level Setting. BMC Medical Education, 15, 27. https://doi.org/10.1186/s12909-015-0317-2

Muzyk, A. J., Fuller, S., Jiroutek, M.R., Grochowski, C. O., Butler, A. C., \& May, D. B. (2015). Implementation of a Flipped Classroom Model to Teach Psychopharmacotherapy to Third-Year Doctor of Pharmacy (PharmD) Students. Pharmacy Education, 15, 44-53.

Nakanishi, T., Goto, T., Kobuchi, T., Kimura, T., Hayashi, H., \& Tokuda, Y. (2017). The Effects of Flipped Learning for Bystander Cardiopulmonary Resuscitation on Undergraduate Medical Students. International Journal of Medical Education, 8, 430-436. https://doi.org/10.5116/ijme.5a2b.ae56

Ng, E. M. W. (2018). Integrating Self-Regulation Principles with Flipped Classroom Pedagogy for First Year University Students. Computers \& Education, 126, 65-74. https://doi.org/10.1016/j.compedu.2018.07.002

Olakanmi, E. E. (2016). The Effects of a Flipped Classroom Model of Instruction on Students' Performance and Attitudes towards Chemistry. Journal of Science Education and Technology, 26, 1-11. https://doi.org/10.1007/s10956-016-9657-x

Olitsky, N. H., \& Cosgrove, S. B. (2016). The Better Blend? Flipping the Principles of Mi- 
croeconomics Classroom. International Review of Economics Education, 21, 1-11. https://doi.org/10.1016/j.iree.2015.10.004

Rahman, A. A., Aris, B., Mohamed, H., \& Zaid, N. M. (2014). The Influences of Flipped Classroom: A Meta-Analysis. 2014 IEEE 6th Conference on Engineering Education, Kuala Lumpur, 9-10 December 2014, 24-28. https://doi.org/10.1109/ICEED.2014.7194682

Rodrigues, R. L., Sedraz, J., Ramos, J. L. C., de Souza, F. D. F., \& Gomes, A. S. (2016). Uma Abordagem de Regressão Múltipla para Validação de Variáveis de Autorregulação da Aprendizagem em Ambientes de LMS. Brazilian Symposium on Computers in Education, 27, 916. https://doi.org/10.5753/cbie.sbie.2016.916

Rodriguez, G., Diez, J., Perez, N., Banos, J. E., \& Carrio, M. (2019). Flipped Classroom: Fostering Creative Skills in Undergraduate Students of Health Sciences. Thinking Skills and Creativity, 33, Article ID: 100575. https://doi.org/10.1016/j.tsc.2019.100575

Rosenthal, R. (1979). The "File Drawer Problem" and Tolerance for Null Results. Psychological Bulletin, 86, 638-641. https://doi.org/10.1037/0033-2909.86.3.638

Scott, C. E., Green, L. E., \& Etheridge, D. L. (2016). A Comparison between Flipped and Lecture-Based Instruction in the Calculus Classroom. Journal of Applied Research in Higher Education, 8, 252-264. https://doi.org/10.1108/JARHE-04-2015-0024

Sengel, E. (2014). Using the "Flipped Classroom" to Enhance Physics Achievement of the Prospective Teacher Impact of Flipped Classroom Model on Physics Course. Journal of the Balkan Tribological Association, 20, 488-497.

Sengel, E. (2016). To FLIP or Not to FLIP: Comparative Case Study in Higher Education in Turkey. Computers in Human Behavior, 64, 547-555. https://doi.org/10.1016/j.chb.2016.07.034

Sergis, S., Sampson, D. G., \& Pelliccione, L. (2018). Investigating the Impact of Flipped Classroom on Students' Learning Experiences: A Self-Determination Theory Approach. Computers in Human Behavior, 78, 368-378. https://doi.org/10.1016/j.chb.2017.08.011

Sezer, B. (2017). The Effectiveness of a Technology-Enhanced Flipped Science Classroom. Journal of Educational Computing Research, 55, 471-494. https://doi.org/10.1177/0735633116671325

Shiau, S., Kahn, L. G., Platt, J., Li, C., Guzman, J. T., Kornhauser, Z. G. et al. (2018). Evaluation of a Flipped Classroom Approach to Learning Introductory Epidemiology. BMC Medical Education, 18, 63. https://doi.org/10.1186/s12909-018-1150-1

Smallhorn, M. (2017). The Flipped Classroom: A Learning Model to Increase Student Engagement Not Academic Achievement. Student Success, 8, 43-53. https://doi.org/10.5204/ssj.v8i2.381

Sommer, M., \& Ritzhaupt, A. (2018). Impact of the Flipped Classroom on Learner Achievement and Satisfaction in an Undergraduate Technology Literacy Course. Journal of Information Technology Education: Research, 17, 59-182. https://doi.org/10.28945/4059

Strayer, J. (2007). The Effects of the Classroom Flip on the Learning Environment: A Comparison of Learning Activity in and Traditional Classroom and a Flip Classroom That Used and Intelligent Tutoring System. Ph.D. Dissertation, Department of Education, Ohio State University.

Sun, J. C. Y., \& Wu, Y. T. (2016). Analysis of Learning Achievement and Teacher-Student Interactions in Flipped and Conventional Classrooms. The International Review of Research in Open and Distributed Learning, 17, 79-99.

https://doi.org/10.19173/irrodl.v17i1.2116 
Sun, Z. R., Xie, K., \& Anderman, L.H. (2018). The Role of Self-Regulated Learning in Student's Success in Flipped Undergraduate Math Courses. The Internet and Higher Education, 36, 41-53. https://doi.org/10.1016/j.iheduc.2017.09.003

Talbert, R. (2015). Inverting the Transition-to-Proof Classroom. PRIMUS, 25, 614-626. https://doi.org/10.1080/10511970.2015.1050616

Thai, T. N. T., Wever, B. D., \& Valcke, M. (2017). The Impact of a Flipped Classroom Design on Learning Performance in Higher Education: Looking for the Best "Blend" of Lectures and Guiding Questions with Feedback. Computers \& Education, 107, 113-126. https://doi.org/10.1016/j.compedu.2017.01.003

Tomas, L., Evans, N., Doyle, T., \& Skamp, K. (2019). Are First Year Students Ready for a Flipped Classroom? A Case for a Flipped Learning Continuum. International Journal of Educational Technology in Higher Education, 16, 1-22. https://doi.org/10.1186/s41239-019-0135-4

Tse, W. S., Choi, L. Y. A., \& Tang, W. S. (2017). Effects of Video-Based Flipped Class Instruction on Subject Reading Motivation. British Journal of Educational Technology, 50, 385-398. https://doi.org/10.1111/bjet.12569

Tucker, C. R. (2013). Blended Learning in Grades 4-12: Leveraging the Power of Technology to Create Student-Centered Classrooms. Corwin.

Turra, H., Carrasco, V., Gonzalez, C., Sandoval, V., \& Yanez, S. (2019). Flipped Classroom Experiences and Their Impact on Engineering Students' Attitudes towards University-Level Mathematics. Higher Education Teaching, 4, 136-155.

https://doi.org/10.1080/23752696.2019.1644963

Tusa, N., Sointu, E., Kastarinen, H., Valtonen, T., Kaasinen, A., Hirsto, L. et al. (2018). Medical Certificate Education: Controlled Study between Lectures and Flipped Classroom. BMC Medical Education, 18, 243-248.

https://doi.org/10.1186/s12909-018-1351-7

Wang, J. Y., Jou, M., Lv, Y. Z., \& Huang, C. C. (2018a). An Investigation on Teaching Performances of Model-Based Flipping Classroom for Physics Supported by Modern Teaching Technologies. Computers in Human Behavior, 84, 36-48. https://doi.org/10.1016/j.chb.2018.02.018

Wang, J., An, N., \& Wright, C. (2018b). Enhancing Beginner Learners' Oral Proficiency in a Flipped Chinese Foreign Language Classroom. Computer Assisted Language Learning, 31, 490-521. https://doi.org/10.1080/09588221.2017.1417872

Wasserman, N. H., Quint, C., Norris, S. A., \& Carr, T. (2015). Exploring Flipped Classroom Instruction in Calculus iii. International Journal of Science \& Mathematics Education, 15, 1-24. https://doi.org/10.1007/s10763-015-9704-8

Wasserman, N. H., Quint, C., Norris, S. A., \& Carr, T. (2017). Exploring Flipped Classroom Instruction in Calculus III. International Journal of Science \& Mathematics Education, 15, 545-568. https://doi.org/10.1007/s10763-015-9704-8

Webster, D. R., \& Majerich, D. M. (2014). Flipping Fluid Mechanics Improved Student Engagement and Learning via Web-Based Applications. Proceedings of Ocean Sciences Meeting, New York, 31 November 2014.

Xu, P., Chen, Y. Y., Nie, W. B., Wang, Y., Song, T. J., Li, H. R. et al. (2019). The Effectiveness of a Flipped Classroom on the Development of Chinese Nursing Students' Skill Competence: A Systematic Review and Meta-Analysis. Nurse Education Today, 80, 6777. https://doi.org/10.1016/j.nedt.2019.06.005

Yu, Z., \& Wang, G. (2016). Academic Achievements and Satisfaction of the Clicker-Aided Flipped Business English Writing Class. Journal of Chengdu Normal University, 19, 298- 
312.

Zainuddin, Z., Haruna, H., Li, X., Zhang, Y., \& Chu, S. (2019). A Systematic Review of Flipped Classroom Empirical Evidence from Different Fields: What Are the Gaps and Future Trends? On the Horizon, 27, 72-86. https://doi.org/10.1108/OTH-09-2018-0027

Zhu, W., \& Xie, W. (2018). Evaluating Instructional Effects of Flipped Classroom in University: A Case Study on Electronic Business Course. International Journal of Distance Education Technologies, 16, 45-55.

https://doi.org/10.4018/IJDET.2018010103

Zhu, Y. C., Zhang, W., He, Y., Wen, J. B., \& Li, M. Y. (2018). Design and Implementation of Curriculum Knowledge Ontology-Driven SPOC Flipped Classroom Teaching Model. Educational Sciences: Theory \& Practice, 18, 1351-1374.

Zupanec, V. S., Radulovic, B. N., Pribicevic, T. Z., Miljanovic, T. G., \& Zdravkovic, V. G. (2018). Determination of Educational Efficiency and Student's Involvement in the Flipped Biology Classroom in Primary School. Journal of Baltic Science Education, 17, 162-172. https://doi.org/10.33225/jbse/18.17.162 


\section{Appendix}

Table A1. General information of 63 papers included in the meta-analysis.

\begin{tabular}{|c|c|c|c|c|c|c|c|c|c|}
\hline Author \& Year & $\begin{array}{l}\text { Study } \\
\text { Design }\end{array}$ & $\begin{array}{l}\text { Sample } \\
\text { Size }\end{array}$ & $\begin{array}{l}\text { Learning } \\
\text { Stage }\end{array}$ & $\begin{array}{l}\text { Subject } \\
\text { Area }\end{array}$ & $\begin{array}{l}\text { Knowledge } \\
\text { Type }\end{array}$ & $\begin{array}{l}\text { Instructor } \\
\text { Equivalence }\end{array}$ & $\begin{array}{l}\text { Intervention } \\
\text { Duration }\end{array}$ & $\mathrm{g}$ & SEg \\
\hline Anderson et al., 2017 & TGPPD & 70 & university & Medicine & CK & same instructor & 6 weeks & -0.106 & 0.237 \\
\hline Asiksoy and Ozdamli, 2016 & TGPPD & 66 & university & Natural Science & CK & same instructor & 8 weeks & 0.577 & 0.249 \\
\hline Asiksoy and Ozdamli, 2017 & TGPPD & 94 & university & Natural Science & $\mathrm{CK}$ & same instructor & 10 weeks & 1.42 & 0.229 \\
\hline Balaban et al., 2016 & TGPD & 729 & university & Social science & CK & same instructor & 15 weeks & 0.604 & 0.076 \\
\hline Burgoyne and Eaton, 2018 & TGPD & 267 & university & Social science & $\mathrm{CK}$ & $\begin{array}{l}\text { different } \\
\text { instructor }\end{array}$ & 1 semester & 0.237 & 0.123 \\
\hline $\begin{array}{l}\text { Burnham and Mascenik, } \\
2018\end{array}$ & TGPPD & 179 & university & Medicine & $\mathrm{PK}$ & same instructor & 10 weeks & -0.287 & 0.15 \\
\hline Cabi, 2018 & TGPPD & 59 & university & $\begin{array}{l}\text { Engineering \& } \\
\text { Technology }\end{array}$ & $\mathrm{CK}$ & not available & 4 weeks & -0.086 & 0.257 \\
\hline Chao et al., 2015 & TGPPD & 91 & high school & $\begin{array}{l}\text { Engineering \& } \\
\text { Technology }\end{array}$ & $\mathrm{PK}$ & same instructor & 8 weeks & 0.782 & 0.216 \\
\hline Chis et al., 2018 & other & 106 & university & $\begin{array}{l}\text { Engineering \& } \\
\text { Technology }\end{array}$ & $\mathrm{PK}$ & same instructor & 3 weeks & -0.218 & 0.193 \\
\hline Chiu et al., 2017 & TGPD & 59 & university & Medicine & $\mathrm{PK}$ & same instructor & 1 hour & 0.868 & 0.269 \\
\hline Cho et al., 2015 & other & 47 & university & Natural Science & $\mathrm{PK}$ & same instructor & 1 semester & 0.317 & 0.29 \\
\hline Choi and Lee, 2018 & TGPPD & 79 & university & Social science & $\mathrm{PK}$ & same instructor & 1 semester & 0.479 & 0.226 \\
\hline Chutinan et al., 2018 & TGPD & 140 & university & Medicine & $\mathrm{PK}$ & not available & 1 semester & 1.445 & 0.189 \\
\hline Chyr et al., 2017 & other & 69 & university & Social science & $\mathrm{PK}$ & same instructor & 1 semester & 0.089 & 0.238 \\
\hline Cruzado and Roman, 2015 & TGPD & 120 & university & $\begin{array}{l}\text { Engineering \& } \\
\text { Technology }\end{array}$ & CK & same instructor & 1 semester & -0.193 & 0.186 \\
\hline Davies et al., 2013 & other & 112 & university & Social science & $\mathrm{PK}$ & same instructor & 5 weeks & 0.221 & 0.189 \\
\hline Day, 2018 & TGPD & 217 & university & Medicine & CK & same instructor & 1 semester & 0.066 & 0.135 \\
\hline Ekmekci, 2017 & TGPPD & 43 & university & Humanities & $\mathrm{PK}$ & same instructor & 15 weeks & 1.804 & 0.358 \\
\hline Elian and Hamaidi, 2018 & TGPPD & 44 & university & Natural Science & CK & same instructor & 1 semester & 1.468 & 0.335 \\
\hline Elmaadaway, 2017 & TGPD & 58 & university & Social science & $\mathrm{PK}$ & same instructor & 8 weeks & 2.418 & 0.343 \\
\hline Fadol et al., 2018 & TGPD & 86 & university & Social science & CK & same instructor & 18 weeks & 0.847 & 0.224 \\
\hline Fleagle et al., 2017 & other & 483 & university & Medicine & $\mathrm{PK}$ & same instructor & 1 semester & -0.184 & 0.091 \\
\hline Goff et al., 2018 & TGPD & 629 & university & Social science & $\mathrm{CK}$ & $\begin{array}{l}\text { different } \\
\text { instructor }\end{array}$ & 1 semester & 0.601 & 0.082 \\
\hline Harrington et al., 2015 & TGPD & 82 & university & Medicine & CK & $\begin{array}{l}\text { different } \\
\text { instructor }\end{array}$ & 1 semester & 0.083 & 0.219 \\
\hline Hotle and Garrow, 2016 & TGPD & 59 & university & $\begin{array}{l}\text { Engineering \& } \\
\text { Technology }\end{array}$ & $\mathrm{PK}$ & same instructor & 1 semester & -0.031 & 0.263 \\
\hline Jong, 2017 & TGPD & 72 & $\begin{array}{l}\text { secondary } \\
\text { school }\end{array}$ & Humanities & $\mathrm{CK}$ & same instructor & 9 days & 0.921 & 0.245 \\
\hline Khan and Watson, 2018 & TGPD & 943 & university & Natural Science & CK & same instructor & 1 semester & 0.043 & 0.065 \\
\hline
\end{tabular}




\section{Continued}

\begin{tabular}{|c|c|c|c|c|c|c|c|c|c|}
\hline Kim et al., 2017 & TGPPD & 202 & university & Medicine & $\mathrm{PK}$ & same instructor & 10 weeks & 4.452 & 0.262 \\
\hline Kim et al., 2017 & TGPD & 51 & university & Humanities & $\mathrm{CK}$ & same instructor & 12 weeks & -0.018 & 0.276 \\
\hline Kostaris et al., 2017 & TGPD & 46 & $\begin{array}{l}\text { secondary } \\
\text { school }\end{array}$ & Social science & CK & same instructor & 8 weeks & 0.918 & 0.305 \\
\hline Kurt, 2017 & TGPPD & 62 & university & Humanities & $\mathrm{CK}$ & same instructor & 14 weeks & 0.933 & 0.265 \\
\hline Leis et al., 2015 & TGPPD & 44 & university & Humanities & CK & same instructor & 10 weeks & 1.378 & 0.331 \\
\hline Lento, 2016 & TGPD & 189 & university & Social science & $\mathrm{CK}$ & same instructor & 12 weeks & 0.26 & 0.146 \\
\hline Lin and Hwang, 2018 & TGPD & 49 & university & Humanities & PK & same instructor & 18 weeks & 1.982 & 0.36 \\
\hline Lin et al., 2018 & TGPPD & 68 & university & Humanities & CK & same instructor & 10 weeks & 2.017 & 0.296 \\
\hline Liou et al., 2016 & TGPPD & 92 & university & Natural Science & $\mathrm{CK}$ & same instructor & 18 weeks & 1.43 & 0.232 \\
\hline \multirow{4}{*}{ Lo et al., 2018} & TGPPD & 244 & $\begin{array}{l}\text { secondary } \\
\text { school }\end{array}$ & Natural Science & CK & same instructor & $\begin{array}{l}10-14 \\
\text { weeks }\end{array}$ & 0.293 & 0.128 \\
\hline & TGPPD & 55 & $\begin{array}{l}\text { secondary } \\
\text { school }\end{array}$ & Natural Science & CK & same instructor & $\begin{array}{l}10-14 \\
\text { weeks }\end{array}$ & 0.714 & 0.274 \\
\hline & TGPPD & 24 & $\begin{array}{l}\text { secondary } \\
\text { school }\end{array}$ & Humanities & CK & same instructor & $\begin{array}{l}10-14 \\
\text { weeks }\end{array}$ & 0.828 & 0.412 \\
\hline & TGPPD & 22 & $\begin{array}{l}\text { secondary } \\
\text { school }\end{array}$ & Social science & CK & $\begin{array}{l}\text { different } \\
\text { instructor }\end{array}$ & $\begin{array}{l}10-14 \\
\text { weeks }\end{array}$ & -0.224 & 0.412 \\
\hline Lucchetti et al., 2018 & TGPPD & 166 & university & Medicine & $\mathrm{PK}$ & same instructor & 1 semester & 0.326 & 0.156 \\
\hline Mason et al., 2013 & TGPPD & 40 & university & $\begin{array}{l}\text { Engineering \& } \\
\text { Technology }\end{array}$ & $\mathrm{PK}$ & same instructor & 1 semester & -1.157 & 0.336 \\
\hline Mattis, 2012 & TGPPD & 48 & university & Natural Science & $\mathrm{CK}$ & same instructor & 1 hour & 1.132 & 0.307 \\
\hline McCabe et al., 2017 & TGPPD & 45 & university & Medicine & CK & not available & 1 semester & -0.996 & 0.315 \\
\hline Missildine et al., 2013 & other & 316 & university & Medicine & CK & $\begin{array}{l}\text { different } \\
\text { instructor }\end{array}$ & 1 semester & 0.435 & 0.115 \\
\hline Moraros et al., 2015 & TGPPD & 112 & university & Medicine & $\mathrm{CK}$ & same instructor & 13 weeks & 2.123 & 0.236 \\
\hline Muzyk et al., 2015 & TGPPD & 50 & university & Medicine & $\mathrm{CK}$ & $\begin{array}{l}\text { different } \\
\text { instructor }\end{array}$ & 1 semester & 0.699 & 0.291 \\
\hline Nakanishi et al., 2017 & TGPD & 108 & university & Medicine & PK & $\begin{array}{l}\text { different } \\
\text { instructor }\end{array}$ & 6 months & 0.1 & 0.191 \\
\hline Olakanmi, 2016 & TGPPD & 66 & $\begin{array}{l}\text { secondary } \\
\text { school }\end{array}$ & Natural Science & CK & same instructor & 3 weeks & 1.46 & 0.274 \\
\hline $\begin{array}{l}\text { Olitsky and Cosgrove, } \\
2016\end{array}$ & TGPD & 240 & university & Social science & CK & same instructor & 1 semester & 0.312 & 0.129 \\
\hline Sengel, 2014 & TGPPD & 74 & university & Natural Science & CK & same instructor & 7 weeks & 0.029 & 0.231 \\
\hline Sengel, 2016 & TGPPD & 96 & university & Natural Science & CK & same instructor & 1 semester & 0.561 & 0.209 \\
\hline Sezer, 2017 & TGPPD & 68 & $\begin{array}{l}\text { secondary } \\
\text { school }\end{array}$ & Natural Science & CK & same instructor & 2 weeks & 0.923 & 0.253 \\
\hline Shiau et al., 2018 & TGPD & 150 & university & Medicine & CK & same instructor & 1 semester & 0.085 & 0.163 \\
\hline Smallhorn, 2017 & TGPD & 363 & university & Social science & CK & not available & 1 semester & -0.013 & 0.105 \\
\hline $\begin{array}{l}\text { Sommer and Ritzhaupt, } \\
\qquad 2018\end{array}$ & TGPD & 72 & university & Social science & $\mathrm{PK}$ & $\begin{array}{l}\text { different } \\
\text { instructor }\end{array}$ & 15 weeks & 0.17 & 0.236 \\
\hline
\end{tabular}




\section{Continued}

\begin{tabular}{cccccccccccc}
\hline Sun and Wu, 2016 & TGPPD & 181 & university & Natural Science & CK & same instructor & 1 semester & 0.453 & 0.15 \\
Thai et al., 2017 & other & 45 & university & Social science & CK & same instructor & 6 weeks & 0.827 & 0.306 \\
Tusa et al., 2018 & TGPPD & 79 & university & Medicine & PK & same instructor & 1 semester & 1.391 & 0.249 \\
Wang et al., 2018a & TGPD & 61 & university & Humanities & CK & same instructor & 16 weeks & 0.143 & 0.253 \\
Wang et al., 2018b & other & 74 & high school & Natural Science & PK & same instructor & 1 semester & -0.023 & 0.23 \\
Wasserman et al., 2017 & TGPD & 151 & university & Natural Science & CK & different & instructor & 1 semester & 0.44 & 0.164 \\
Yu and Wang, 2016 & TGPPD & 71 & university & Humanities & CK & same instructor & 16 weeks & 0.496 & 0.238 \\
Zhu and Xie, 2018 & other & 142 & university & Social science & CK & same instructor & 8 weeks & 0.363 & 0.168 \\
Zhu et al., 2018 & TGPD & 82 & university & Social science & CK & same instructor & 1 semester & 0.805 & 0.228 \\
Zupanec et al., 2018 & TGPPD & 112 & elementary & Social science & CK & same instructor & 6 weeks & 2.132 & 0.236 \\
\hline
\end{tabular}

Note. TGPPD: two group pretest posttest design; TGPD: two group posttest design; CK: conceptual knowledge; PK: procedural knowledge; SEg: standard error of Hedges' g. 